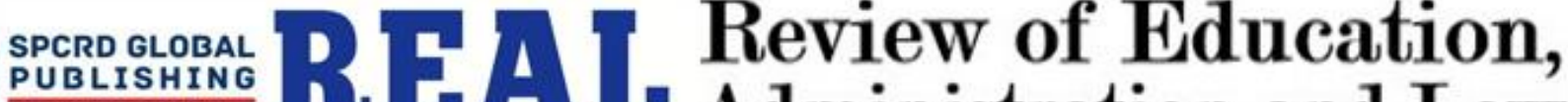

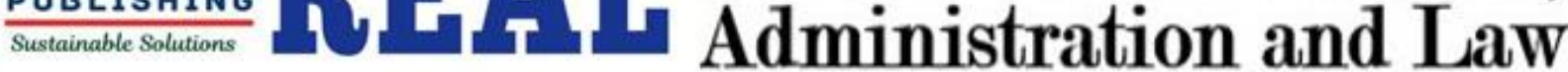 \\ Journal homepage: http://real.spcrd.org \\ ISSN (Print): 2708-1788
}

\section{Impact Assessment of Devolution Paradigm in Primary Education Sector: Policy Initiatives and Budgetary Allocations in Punjab Province}

\author{
a Raheel Abbas, ${ }^{\mathrm{b}}$ Muhammad Asghar, ${ }^{\mathrm{c}}$ Rashid Saeed \\ a Assistant School of Economics, Bahauddin Zakariya University, Multan: raheel.kalroo@bzu.edu.pk \\ ${ }^{b}$ Department of Economics, BZU Bahadur Sub Campus Layyah: m.asghar.ly@gmail.com \\ c Department of Business Administration, BZU Bahadur Sub Campus Layyah: rashid.saeed@bzu.edu.pk
}

Corresponding author's email address: m.asghar.ly@gmail.com

\begin{tabular}{ll}
\hline ARTICLE DETAILS & ABSTRACT \\
\hline History: & $\begin{array}{l}\text { The study aims to empirically testify the devolution intervention in the } \\
\text { budgetary allocations of the primary education sector of the Punjab } \\
\text { Accepted 18 October } 2019\end{array}$ \\
$\begin{array}{l}\text { Available online } 31 \text { December } \\
\text { province. It addresses the question; whether devolution intervention has } \\
\text { an impact on primary education policy and input indicators or not? This }\end{array}$ \\
Keywords: & $\begin{array}{l}\text { study is based on Content Analysis to derive a meaningful conclusion } \\
\text { about policy interventions. The budgetary interventions are verified by }\end{array}$ \\
Education Sector, Multivariate & $\begin{array}{l}\text { Multivariate Analysis of Variance (MANOVA) and Descriptive } \\
\text { Discriminant Analysis (DDA) to measure the impact of devolution }\end{array}$ \\
ANOVA, Descriptive & intervention. The analysis shows that there is no mere shift in policy \\
Discriminant Analysis & initiatives and budgetary allocations. However, the primary education \\
& sector is relatively better as compared to the pre-devolution period but \\
still, a lot of interventions are required for further improvement.
\end{tabular}

E41, E51, I21, C13

DOI: $10.47067 /$ real.v2i2.15

(C) 2019 The authors. Published by SPCRD Global Publishing. This is an open access article under the Creative Commons Attribution-

Non Commercial 4.0

\section{Introduction}

Devolution refers to the transfer of powers from the central government to provincial government/states or local authorities either by the constitution or conventional statutes. The phenomenon gained importance during the 2oth century when US devolved powers from Washington D.C. to states. Later, it experienced throughout the World. The most notable devolution occurs during the '8os and 9o's when France and the United Kingdom followed the phenomenon respectively. Before they were most centralized economies. In most nations, devolution viewed to reduce regional, racial, religious and ethnic issues such as in Sri Lanka, Indonesia, Finland, and Spain1. The local government system (2002) and the 18th amendment in the Constitution of Pakistan (2010) were a policy paradigm shift of 
powers from provincial level to the district level and federal level to provincial level respectively in Pakistan. The provinces become autonomous to formulate their policies, budgets, and other service sector development. The education sector was also one of the key sectors transferred to the provinces.

According to economists, the basic education is "either a minimum number of years of schooling in which a beneficiary is expected to achieve a level of numeracy and literacy that can be maintained through out-of-school services after completion or the maximum number of years that the government can afford to provide for all or most of its citizens." 2 Therefore, it mandatory for all nations to provide universal primary education to all of his citizens as a basic provision. Primary education remained a policy agenda for the governments, non-governmental organizations, researchers and autonomous bodies to reduce massive poverty and to make primary education accessible emphasized in the "World Conference on Education for All (EFA)" held in Jomtien in 1990. The conference declaration urged participating countries to meet the basic learning needs of the massive illiterate population. The same objectives were reaffirmed in the Dakkar World Education Forum in April 2000 and Millennium Summit in September 200o. Pakistan also signed the Dakar framework of actions and adopted Millennium Development Goals (MDG's). The 100 percent achievement of universal primary education until 2015 was one of the main goals of that summit.

The Government of Pakistan formulated a national action plan to achieve education for all goals in the year 2002. The comprehensive initiative has been taken during the implementation of the local government system since 2004 followed by the government of Punjab. These initiatives were started under the program "Punjab Education Sector Reforms Program-PESRP" started with the help of the World Bank. The directorate of staff development was established in August 2004 as a sole agency for teacher's professional capacity development. Since 2004; school fees' abolished, free textbooks provided, a monthly stipend to girls of selected deprived rural areas schools provided, free edible oil and free lunch to school children under the Tawana Pakistan Program. The reforms in the education sector gained importance during the implementation of the 18th Amendment by the National Assembly of Pakistan on 10th April 2010 with the inclusion of Article 25-A. Article 25-A of the Constitution states that "State shall provide free and compulsory education to all children of the age of five to sixteen years in such a manner as may be determined by law". In the 18th amendment (2010), the curriculum declared as a provincial responsibility. The provinces started their legislation for the implementation of Article 25-A.

Chief Minister Reform's Program launched in 2011 to infuse quality and better governance is a main operational policy framework for the school education department since the devolution of the service sector. The main reforms were about student attendance, teacher presence, and recruitment of qualified teachers, availability, and functioning of basic facilities and supervision by district administration. Some monetary benefits also provided to best performer teachers. The government of Punjab started Compulsory Primary Education Reforms (5-16 years) aimed at free and compulsory access to education.

After devolution, the government of Punjab mainly adopted the national education policy of 2009. The main education policy actions focused achievement of universal free primary education by 2015 and secondary education by 2025, promoting access and equity in early childhood education, achieving 86 percent literacy rate, enhancing education budget up to 7\% of GDP by 2015, elimination of social inclusion and provision of increased opportunities to marginal class quality education on national standards, improving quality of education, introduction of a common curriculum framework for public and private 
sectors, improving educational inputs, processes, and output standard, merit-based teacher recruitment and provision of missing facilities.

Punjab School Road Map (2011) focused on improving government schools regarding educational standards set by the national education policy of 2009 and the expansion of the Punjab Education Foundation (PEF) to enhance the quality of learning in private schools. The road map essentially concentrates on strong central coordination, scripted lessons and supporting material, incentives for the high performer, the fulfillment of student's basic needs, hiring management staff with the competitive process, universal standards and curriculum, evidence-based interventions and competitive salaries to the teaching staff. To achieve these objectives, Chief Minister Secretariat established to coordinate with secretary schools, district chief executive officers, Program Management and Implementation Unit (PMIU), Punjab Examination Commission (PEC), some collaboration with external partners like World Bank and DFID.

Apart from the policy initiatives, budgetary allocations are most important to accomplish the objectives defined under education policy. The expenditures on primary education have increased threefold in absolute terms but reduced in terms of percent of total education expenditures and gross regional product (GRP). The budgetary requirement is still less than 2 percent of GDP instead of increasing to $4 \%$ as per the national action plan to accelerate education-related MDG's-2013 (NEMIS 2012-13) and to $7 \%$ as per national education policy of 2009. The primary education budgetary indicators from 2005-06 to 2015-16 are given in table 1.

Table 1-Overview of Education Expenditures of Punjab Province

\begin{tabular}{|c|c|c|c|c|c|}
\hline Year & $\begin{array}{l}\text { Total } \\
\text { Expenditure } \\
\text { on } \\
\text { Education1 } \\
\text { (Million) }\end{array}$ & $\begin{array}{l}\text { Expenditure } \\
\text { on Primary } \\
\text { Education1 } \\
\text { (Million) }\end{array}$ & $\begin{array}{l}\text { Primary } \\
\text { Education } \\
\text { Expenditure } \\
\% \text { of Total } \\
\text { Education } \\
\text { Expenditure }\end{array}$ & $\begin{array}{l}\text { Total } \\
\text { Education } \\
\text { Expenditure } \\
\% \text { of Punjab } \\
\text { GRP2 }\end{array}$ & $\begin{array}{l}\text { Primary } \\
\text { Education } \\
\text { Expenditure } \\
\% \text { of Punjab } \\
\text { GRP2 }\end{array}$ \\
\hline $2005-06$ & 68890 & 34300 & 49.79 & 1.62 & 0.80 \\
\hline 2006-07 & 74801 & 39984 & 53.45 & 1.57 & 0.84 \\
\hline 2007-08 & 100946 & 45264 & 44.84 & 1.85 & 0.83 \\
\hline 2008-09 & 105234 & 50235 & 47.74 & 1.53 & 0.73 \\
\hline $2009-10$ & 136889 & 66272 & 48.41 & 1.77 & 0.86 \\
\hline 2010-11 & 155154 & 72913 & 46.99 & 1.61 & 0.76 \\
\hline $2011-12$ & 191978 & 83912 & 43.71 & 1.81 & 0.79 \\
\hline 2012-13 & 220576 & 94996 & 43.07 & 1.85 & 0.80 \\
\hline $2013-14$ & 232566 & 98962 & 42.55 & 1.73 & 0.74 \\
\hline $2014-15$ & 259629 & 108579 & 41.82 & 1.76 & 0.73 \\
\hline $2015-16$ & 286506 & 110840 & 38.69 & 1.81 & 0.70 \\
\hline \multicolumn{6}{|c|}{$\begin{array}{l}\text { Source: 1Annex-2-World Bank staff calculations: Punjab Social Sector Public } \\
\text { Expenditures Review } 2013 \text { (Finance Accounts of the Province, Accountant General of } \\
\text { Punjab) and Institute of Social and Policy Sciences (I-SAPS). } \\
\text { 2Own Calculation based on a percentage of Gross Regional Product estimates from }\end{array}$} \\
\hline
\end{tabular}


Punjab Bureau of Statistics (ADP Strategy Paper) calculated at current market prices.

Education is now provincial subject as per the 18th constitutional amendment legislated by the parliament during April 2010 and provinces are fully authorized and autonomous in their education policy and other interventions. In Punjab, there are almost 4 percent mosque schools, 73 percent primary schools, 13 percent middle schools, 9 percent high schools and only 1 percent higher secondary schools (Punjab School Education Department). It is the largest education sector in Punjab in terms of size as well as budget and therefore needs careful administration (Punjab Development Statistics, 2014-15). The main objective of the study is the impact assessment of primary education input indicators in the Punjab province in lieu of the devolution intervention. The study is concerned with the question of whether policy interventions and budgetary allocations indicators of primary education have improved during the postdevolution period or not? The impact evaluation of primary education in Punjab is very important to know regarding the UNDP goal of Universal Primary Education and the Punjab government's goal of Compulsory Primary Education for every child. Therefore, the author tried to investigate the subject matter and to make some policy lessons for the better provisions and achievement of learning achievement of compulsory primary education.

\section{Literature Review}

Education is very important in terms of social welfare and economic development. It reduces poverty because educated peoples earn more as compared to those are illiterate. Ultimately, the outcome is economic prosperity and growth (Hannum \& Buchman, 2004; Herz \& Sperling, 2003). Better education also improves political participation, political power and equitable sharing of economic paradigms (Birdsall, 1999). Therefore, the main agenda for the government may be an improvement in the education system to attract, retain and train the children.

Economist claims that devolution increases the efficiency in resource allocation. Efficiency increases if responsibilities shifted from the federal government to states/provinces. Many researchers claim this statement like Oates (1972), Inman (1985), Gramlich (1987), Gingrich (1995), Rich and White (1996) and Kincaid (1998). Tannenwald (2001) discussed the devolution in the United States in detail. He concluded that efficiency in the US has improved the health and education sector due to the devolution revolution.

The effectiveness of education policy is measured in terms of outcome variables. The increase in access, equity, and quality of learning achievement will reflect the success in education policy. There may exist a trade-off between access and learning achievement indicators. Because the increase in enrolment raises the pupil-teacher ratio and hence a negative impact on the quality of education, pupil's attendance and drop out ratio (DFID, 2005; White, 2004). The government must provide extra buildings of schools, classrooms, learning the material with increasing enrollment ratio to achieve better learning outcomes (Kingdon, 2005). In case of developing countries, where the population is growing at accelerating growth rates, the quality and quantity of teachers are very low and other allied facilities are also insufficient (Lewin \& Stewart, 2003; Ward, Penny \& Read, 2006).

Khan (2012) analyzed the local government ordinance impact on students' achievements and compared the pre-devolution period with the post-devolution period. Khan found that no improvement observed in the student's achievement. However, the student's score was much lower in small districts during the post-devolution period. In another study by Khan and Yasmeen (2010) found that devolution has a positive impact on enrollment rate and student participation in the primary education sector of 
Punjab province. It also increased the literacy rate of grade-V students due to devolution intervention.

Ayaz and Mirza (2010) compared the impact of devolution on primary education enrollment and drop out of the primary school of low and high literacy. They found a significant increase in enrollment of primary schools and a fall in dropout of grade-I to grade-V Students. Their findings suggest that devolution has improved access to education and a decrease in dropout. Shah, Muhammad, and Hussain (2012) analyzed the implementation of the devolution plan particularly in the perception of district education officers. The primary data was collected through a questionnaire from all provinces of Pakistan. Their findings suggest that the state of implementation of the devolution plan was better in Punjab as compared to KPK and Sindh. While the situations in the Baluchistan province were alarming.

\section{Methodology and Data Issues}

This study is based on qualitative technique called Content Analysis to derive a comprehensive and meaningful conclusion about policy intervention and quantitative techniques like Multivariate Analysis of Variance (MANOVA) and Descriptive Discriminant Analysis (DDA) to measure the impact devolution of interventions. Content analysis is extensively used in qualitative research and impact studies. It is useful to examine any piece of information and communication qualitatively and quantitatively in cultural studies, gender analysis, sociology and psychology, political sciences and other cognitive studies in complex models (Budd, Thorp \& Donohew, 1967). Because it provides a basis to reveal differences in the data, elaborate literature, identify intention, describe behavioral responses and determine the state of the inference to draw (Berelson, 1971). A lot of research studies like Carney (1972), Palmquist (1990), Pratt and Pratt (1995), Neuendorf (2002), Hsieh and Shannon (2005), Elo and Kyngäs (2008) described the systematic approach in both qualitative and quantitative content analysis

When the intervening variable is nominal with or without covariate variable to affect the large no of dependent variables; MANOVA is the best option for multivariate analysis (Zientek \& Thompson, 2009). MANOVA is a powerful statistical technique because it reduces the chances of a type-1 error (Haase \& Ellis, 1987; Huberty \& Morris, 1989). It shows the main effects and interactions and tests whether there are statistically significant differences among groups on a combination of dependent variables or not. Once MANOVA rejects the multivariate null hypothesis, it means at least one group mean is statistically different from another group mean. But cannot tell which group means differ from another group mean. It is the post-hoc test (Stevens, 2002) that tells which mean group is statistically different from another mean group. This post-hoc procedure is called Descriptive Discriminant Analysis.

Based on the above methodologies, the following hypothesis was formulated for the study; Ho: Devolution has no impact on primary education policy and budgetary indicators of Punjab province. H1: Devolution has a significant positive impact on primary education policy and budgetary indicators of Punjab province.

Once the null of overall significance is rejected, another hypothesis tested that the mean differences between pre and post devolution period are the same. The second hypothesis about impact evaluation of devolution is as;

Ho: There are no mean differences between pre and post-devolution periods between dependent variables or groups of variables.

H1: There are significant mean differences between pre and post-devolution periods of dependent variables or groups of variables. 
The data is divided into three sub-periods. The first period refers to devolution of powers from provinces to districts i.e. Local Government System (LGS); the third period refers to devolution of service sector from federal government to provinces and the second period refers to the democratic regime of Pakistan People's Party that lies between first and third period. In the regime of PPP, the budgetary interventions withheld by federation without LGS. The classification of the dummy variables is given to budgetary announcements and their effectiveness. Table 2 shows a clear picture of the data tabulated for the independent variable.

Table 2-The Devolution Dummy Variable Classification and Period Distinction

\begin{tabular}{|c|c|c|}
\hline Year & Devolution Dummy & Devolution Interventions \\
\hline 2004-05 & $\mathrm{O}$ & \multirow{4}{*}{$\begin{array}{l}\text { Local Government System: Transfer of powers } \\
\text { from provinces to districts during the tenure of } \\
\text { President Musharraf. }\end{array}$} \\
\hline $2005-06$ & $\mathrm{o}$ & \\
\hline 2006-07 & $\mathrm{o}$ & \\
\hline 2007-08 & $\mathrm{o}$ & \\
\hline 2008-09 & 1 & \multirow{4}{*}{$\begin{array}{l}\text { The democratic regime of Pakistan People's } \\
\text { Party in which 18th amendment in Constitution } \\
\text { occured during April 2010, and budgetary } \\
\text { interventions withheld by federation without } \\
\text { LGS }\end{array}$} \\
\hline $2009-10$ & 1 & \\
\hline 2010-11 & 1 & \\
\hline 2011-12 & 1 & \\
\hline 2012-13 & 2 & \multirow{4}{*}{$\begin{array}{l}\text { Transfer of service sector from federal to } \\
\text { provinces and provincial autonomy in their } \\
\text { education sector reforms and other } \\
\text { interventions. }\end{array}$} \\
\hline 2013-14 & 2 & \\
\hline $2014-15$ & 2 & \\
\hline $2015-16$ & 2 & \\
\hline
\end{tabular}

The data is sourced from Punjab Development Statistics, Pakistan Education Statistics and Punjab Bureau of Statistics. The units of data being analyzed are expressed in level and percentage.

\section{Empirical Analysis}

The empirical analysis of budgetary interventions is based on MANOVA and DDA. Input indicators consist of only expenditures on primary education. To overcome the trend issue in expenditures on primary education, an additional variable of expenditures as percent of the gross regional product (GRP) has taken. For further comparison, total education expenditures and expenditures as a percent of GRP has included. The first section of the MANOVA; intercept does not make any substantive interpretation except the mean values without interventions, but the second section made a considerable conclusion about devolution hypothesis testing. Four different statistics like Pillai's Trace, Wilks Lambda, Hotelling's Trace, and Roy's Largest Root have calculated with different formulas but converted to the same p-value of F-statistic (Olson, 1976). All four tests are statistically significant at a 5 percent significance level $(\mathrm{p}<0.05)$. This shows that the null hypothesis of no impact of devolution is rejected and the alternative hypothesis is accepted.

Roy's Largest Root has great powers when dependent variables are highly correlated (Huberty \& Oljenik, 2006). Pillai's Trace test results are generally more reliable even the violations of basic 
assumptions of MAOVA (Olson, 1976). Wilks lambda is a more powerful test if there are more than two groups. All four test statistics are reliable in hypothesis testing. The other three columns in table 3 are partial eta squared, non-centrality parameter and observed power (post hoc power). Partial eta squared is like $\mathrm{R}$ square and represents the percentage of variance explained by the given intervention which varies from 67 percent to 97 percent.

Table 3-MANOVA-Multivariate Test

\begin{tabular}{|c|c|c|c|c|c|c|c|c|}
\hline \multicolumn{2}{|l|}{ Effect } & \multirow{2}{*}{\begin{tabular}{|l} 
Value \\
1.00
\end{tabular}} & \multirow{2}{*}{$\begin{array}{l}\text { F } \\
54197 . b\end{array}$} & \multirow{2}{*}{$\begin{array}{l}\mathrm{df} \\
4,5\end{array}$} & \multirow{2}{*}{$\begin{array}{l}\text { Sig. } \\
.000\end{array}$} & \multirow{2}{*}{\begin{tabular}{|l} 
Part. \\
Squared
\end{tabular}} & \multirow{2}{*}{\begin{tabular}{l|l} 
ta Noncent. \\
Parameter
\end{tabular}} & \multirow{2}{*}{$\begin{array}{l}\begin{array}{l}\text { Obs. } \\
\text { Powerd }\end{array} \\
1.00\end{array}$} \\
\hline \multirow{4}{*}{ Intercept } & Pillai's Trace & & & & & & & \\
\hline & Wilks' Lambda & .000 & $54197 \mathrm{~b}$ & 4,5 & .000 & 1.00 & 216788.6 & 1.00 \\
\hline & Hotelling's Trace & 43357 & $54197 \mathrm{~b}$ & 4,5 & .000 & 1.00 & 216788.6 & 1.00 \\
\hline & Roy's Largest Root & 43357 & $54197 \mathrm{~b}$ & 4,5 & .000 & 1.00 & 216788.6 & 1.00 \\
\hline \multirow{4}{*}{ DEV } & Pillai's Trace & 1.33 & 2.98 & 8,12 & .043 & .666 & 23.89 & .748 \\
\hline & Wilks' Lambda & .017 & $8.33 b$ & 8,10 & .002 & .870 & 66.64 & .993 \\
\hline & Hotelling's Trace & 37.28 & 18.64 & 8,8 & .000 & .949 & 149.13 & 1.00 \\
\hline & Roy's Largest Root & 36.72 & $55.08 c$ & 4,6 & .000 & .973 & 220.35 & 1.00 \\
\hline \multicolumn{9}{|c|}{$\begin{array}{l}\text { aDesign: Intercept + DEV. } \\
\text { bExact statistic } \\
\text { cThe statistic is an upper bound on F that yields a lower bound on the significance level. } \\
\text { dComputed using alpha }=.05\end{array}$} \\
\hline
\end{tabular}

The non-centrality parameter is a statistical parameter to test the noncentral distribution of test statistics if the null is not true (Steider \& Fouladi, 1997). When the non-centrality parameter is closer to 1 , it means the null hypothesis is not rejected. If it is greater than 1 , the null is rejected. Its value varies from 24 to 220 of four test statistics and rejects the null. The last column is about observed power. It gives the posterior statistical power of the MANOVA about each test statistic. Its value inversely varies with the p-value. If the value is close to 1 , the null should be rejected and do not be rejected when closer to o. The observed power is close to 1 and hence the null should be rejected in this case.

Once the null hypothesis is rejected in the multivariate test; the test of between-subjects effects becomes necessary to further investigate the variance decomposition. Expenditures on primary education (EPE) and primary education expenditures percent of total education expenditures (PETE) are significant. While primary education expenditures percent of GRP (PEG) and total education expenditures percent of GRP (TEG) are insignificant. It means devolution does not have a significant impact on PEG and TEG. The $F$ value is quite low and partial eta squared shows only 33 percent variation in the variance of PEG explained by the devolution. All other variables variance significantly explained by devolution and hence the test of between-subject effects shows the univariate analysis of variance. The non-centrality parameter and observed powered support the results of MANOVA except PEG and TEG. 
Table 4-Tests of Between-Subjects Effects

\begin{tabular}{|c|c|c|c|c|c|c|c|c|c|}
\hline Source & $\begin{array}{l}\text { Dependent } \\
\text { Variable }\end{array}$ & $\begin{array}{l}\text { Type III Sum } \\
\text { of Squares }\end{array}$ & df & Mean Square & $\mathrm{F}$ & Sig. & $\begin{array}{l}\text { Part. Eta } \\
\text { Squared }\end{array}$ & $\begin{array}{l}\text { Noncent. } \\
\text { Paramete }\end{array}$ & \begin{tabular}{|l} 
Obs. \\
Powere
\end{tabular} \\
\hline \multirow{4}{*}{ DEV } & EPE & $7421973572 a$ & 2 & 3710986786 & 62.8 & .000 & .940 & $125 \cdot 72$ & 1.00 \\
\hline & PETE & $112.95^{b}$ & 2 & 56.47 & 7.23 & .016 & .644 & 14.45 & .803 \\
\hline & PEG & $.009 \mathrm{c}$ & 2 & .004 & 1.97 & .201 & .331 & 3.95 & .295 \\
\hline & TEG & $.043 d$ & 2 & .021 & 1.84 & .220 & .315 & 3.68 & .278 \\
\hline \multicolumn{10}{|c|}{$\begin{array}{l}\text { aR Squared }=.940 \text { (Adjusted R Squared }=.925) \\
\text { bR Squared }=.644 \text { (Adjusted R Squared }=.555) \\
\text { cR Squared }=.331 \text { (Adjusted R Squared }=.163 \text { ) } \\
\text { dR Squared }=.315 \text { (Adjusted R Squared }=.144) \\
\text { eComputed using alpha }=.05\end{array}$} \\
\hline
\end{tabular}

There are many post hoc tests described in the literature but one of the most quoted and reliable is a Tukey test (Warne et al., 2012). When the null hypothesis in MANOVA is rejected, the post hoc test is pre-requisite. It is also called Descriptive Discriminant Analysis. After a test of between-subjects' effects, it is necessary to see which group mean is statistically different from other groups' mean. For example, devolution has a significant effect on expenditures of primary education and 94 percent variation in variance explained by the devolution intervention. The results are given in Table 4 . The post hoc test like Tukey HSD compares the means of three groups of expenditures on primary education with each other to see which group mean is statistically different from others.

In table 5, only the comparison of the post-devolution period (2) i.e. transfer of powers from federal to provincial level in the service sector and autonomy of provincial government in this sector with the democratic regime of PPP (1) and decentralization of powers from provinces to districts (o) i.e. local government system is given. The mean of EPE in regime 2 is statistically different from regime $o$ and 1 at a 1 percent level of significance. The mean of PETE in regime 2 is statistically different from regime 0 but indifferent to regime 1 . The mean differences in primary education expenditures percent of GRP are statistically indifferent from each other. It also confirms that devolution does not have a significant impact on PEG and TEG. The post hoc test results further decompose the variability in the variance of dependent variables into mean differences of each group for each variable.

Table 5-Post Hoc Test: Multiple Comparisons -Tukey HSD

\begin{tabular}{|c|c|c|c|c|c|c|c|}
\hline \multirow[b]{2}{*}{ Dependent Variable } & \multirow{2}{*}{ (I) $\mathrm{DEV}$} & \multirow{2}{*}{$\begin{array}{l}(\mathrm{J}) \\
\mathrm{DEV}\end{array}$} & \multirow{2}{*}{$\begin{array}{l}\text { Mean } \\
\text { Difference } \\
\text { J) }\end{array}$} & \multirow{2}{*}{ (I- $\mid \begin{array}{l}\text { Std. } \\
\text { Error }\end{array}$} & \multirow{2}{*}{ Sig. } & \multicolumn{2}{|c|}{ 95\% Confidence Interval } \\
\hline & & & & & & Lower Bound & Upper Bound \\
\hline \multirow{2}{*}{ EPE } & \multirow{2}{*}{2} & o & $60898.5^{*}$ & 5433 & .000 & 45374.25 & 76422.74 \\
\hline & & 1 & $28978.5^{*}$ & 5868 & .003 & 12210.47 & 45746.68 \\
\hline
\end{tabular}




\begin{tabular}{|c|c|c|c|c|c|c|c|}
\hline \multirow{2}{*}{ PETE } & \multirow{2}{*}{2} & o & $-7.42^{*}$ & 1.974 & .014 & -13.06 & -1.77 \\
\hline & & 1 & -4.83 & 2.13 & .11 & -10.93 & 1.26 \\
\hline \multirow{2}{*}{ PEG } & \multirow{2}{*}{2} & o & -.057 & .033 & .25 & -.15 & .038 \\
\hline & & 1 & -.060 & .036 & .27 & -.16 & .042 \\
\hline \multirow{2}{*}{ TEG } & \multirow{2}{*}{2} & o & .145 & .075 & .19 & -.072 & .362 \\
\hline & & 1 & .057 & .082 & .77 & -.177 & .292 \\
\hline
\end{tabular}

*The mean difference is significant at the .05 level.

\section{Conclusion}

Since the education sector is declared a provincial subject during April 2010 in the 18th amendment under article 25-A. provinces have started their policies and mechanism for the effective utilization of funds allocated to the education sector. Upon careful investigation, the content analysis shows that no emphasis was given to the formulation of provincial education policy. A lot of efforts were made in this regard in the Punjab province but mainly rely upon national education policy 2009. Most of the intervention was successfully implemented as aimed in education policy and Punjab School Education Road Map from pre devolution to the post-devolution period but Punjab province is still lagging the millennium development goals and some goals set in national education policy like allocation of $7 \%$ of GDP to education sector and achievement of 86 percent literacy rate. The government must have to revisit its education policy as per Punjab Growth Strategy to achieve the specified goals.

The second part of the analysis is based on a more quantitative and statistical technique called MANOVA and DDA. The results of MANOVA confirmed the trends as in content analysis. Primary education expenditures have increased over time in absolute amount but decreased to the percentage of total education expenditures and gross regional product. Although devolution explains the variance of all dependent variables jointly and most mean differences among groups are statistically significant which shows the greater allocation of primary education budget over time. Concludingly, the null of no impact of devolution and no mean differences has rejected. Tests of between-subjects' effects and post-hoc tests confirm the mean difference between pre-devolution to the post-devolution period of primary education expenditures and education expenditures as a percent of GRP.

Primary education is an important provision have remained a matter of utmost priority in the World. The government of Punjab has made a lot of effort and taking necessary steps for further improvement since devolution in April 2010. The primary education sub-sector is relatively better as compared to the pre devolution period but still, a lot of interventions are required for further improvement.

\section{References}

Berelson, B. (1971). Content analysis in communication research. New York: Hafner Publishing Company. Budd, R. W., Thorp, R.K., \& Donohew, L. (1967). Content analysis of communications. New York: Macmillan Company.

Carney, T. F. (1972). Content analysis: A technique for systematic inference from communications. Winnipeg, Canada: University of Manitoba Press.

Dakar Framework of Action, Education-For-All (EFA), UNESCO, April 2000

Education for All 2015 National Review Report: Pakistan

EFA Global Monitoring Report, UNESCO, various issues.

Elo, S., \& Kyngäs, H. (2008). The qualitative content analysis process. Journal of Advanced Nursing, 62(1), 
107-115.

Gingrich, N. (1995), To Renew America, New York, HarperCollins.

Gramlich. E. (1987), "Federalism and Federal Deficit Reduction,” National Tax Journal, 40. 299-313.

Haase, R. F., \& Ellis, M. V. (1987). Multivariate analysis of variance. Journal of Counseling Psychology, 34, 404-413. DOI:10.1037/0022-0167.34.4.404

Hsieh, H. F., \& Shannon, S. E. (2005). Three approaches to qualitative content analysis. Qualitative health research, 15(9), 1277-1288.

Huberty, C. J., \& Morris, J. D. (1989). Multivariate analysis versus multiple univariate analyses. Psychological Bulletin, 105, 302-308. DOI:10.1037/0033-2909.105.2.302

Huberty, C. J., \& Olejnik, S. (2006). Applied MANOVA and discriminant analysis. Hoboken, NJ: John Wiley \& Sons.

Inman, R. (1985), "Fiscal Allocation in Federalist Economy,” in J. Quigley and D. Rubinfeld (eds.), American Domestic Priorities, Berkeley, CA, University of California Press.

Khan, A. M. (2012). Impact of Devolution in Education on Students' Achievement at Secondary School Level. Bulletin of Education and Research, 34(1), 43-54

Khan, A. M., \& Mirza, M. S. (2010). Impact of Decentralization in Education on Universalization of Primary Education. Journal of Research and Reflections in Education, 4(2), 90-100.

Khan, A. M., \& Yasmeen, S. (2010). Impact of Devolution on Enrolment Rate at Primary School Level in Selected Districts of Punjab. Journal of Elementary Education, 21(2), 35-52.

Kincaid, J. (1998), “The Devolution Tortoise and the Centralization Hare”, New England Economic Review, May/June 1998, 13-40.

Kingdon, Geeta, 2005. The chapter on Education Economics, in DFID Economists Guide, London, DFID.

Labor Force Survey (LFS), Pakistan Bureau of Statistics, Government of Pakistan

Lewin K M, Stuart J S, (2003), Researching Teacher Education: New Perspectives on Practice, Performance and Policy DFID Research Series 49a

Millennium Development Goals: UNDP; 2000

Ministry of Federal Education and Professional Training, Pakistan

Multiple Indicators Cluster Survey Provincial Reports, UNICEF-Pakistan 2012

Neuendorf, K. A. (2002). The content analysis guidebook. Sage.

Oates, W. (1972), Fiscal Federalism, New York, Harcourt, Brace, Jovanovich.

Olson, C. L. (1976). On choosing a test statistic in multivariate analysis of variance. Psychological Bulletin, 83, 579-586. DOI:10.1037/0033-2909.83.4.579

Pakistan Education Statistics, National Education Management Information System (NEMIS):

Pakistan Social and Living Standards Measurement Survey (PSLMS), Pakistan Bureau of Statistics (PBS), Government of Pakistan

Palmquist, M. E. (1990). The lexicon of the classroom: language and learning in writing classrooms. Doctoral dissertation, Carnegie Mellon University, Pittsburgh, PA

Pratt, C. A. \& Pratt, C. B. (1995). Comparative content analysis of food and nutrition advertisements in Ebony, Essence, and Ladies' Home Journal. Journal of Nutrition Education, 27(1), 11-18.

Provincial Education Sector Plans/Roadmap, Balochistan, Khyber Pakhtunkhwa, Punjab, and Sindh.

Punjab Education Sectors Reforms Program

Rich, R and White W. (1996), "Health Care Policy and the American States: Issues of Federalism," Health Policy, Federalism and the American States, Washington D.C., Urban Institute Press.

Shah, S. M. H., Muhammad, A. A., \& Hussain, K. S. (2012). Implementation of devolution plan; variations in the perceptions of district education officers of Pakistan. J. Res. Reflect. Educ, 1(2), 30-39.

Steider, J. H., \& Fouladi, R. T. (1997). Noncentrality interval estimation and the evaluation of statistical models. In L. L. Harlow, S. A. Mulaik, \& J. H. Steiger (Eds.), What if there were no significance 
tests? (pp. 221-257). Mahwah, NJ: Lawrence Erlbaum Associates.

Stevens, J. P. (2002). Applied multivariate statistics for the social sciences. Mahwah, NJ: Lawrence Erlbaum Associates.

Tannenwald, R. (2001). Devolution in the United States: Theory and Practice. 737-767, Available at SSRN 2095256.

Ward, M., Penny, A., \& Read, T. (2006). Education Reform in Uganda-1997 to 2004: Reflections on Policy, Partnership, Strategy and Implementation (p. 2006). London: Department for International Development.

White, Howard, (2004). Books, buildings, and learning outcomes: an impact evaluation of World Bank Support to basic education in Ghana, Washington DC, OED, World Bank.

Zientek, L. R., \& Thompson, B. (2009). Matrix summaries improve research reports: Secondary analyses using published literature. Educational Researcher, 38, 343-352. doi: 10.3102/o013189Xo9339056 